\title{
Fingertip digital thermal monitoring: a fingerprint for cardiovascular disease?
}

\author{
E. E. van der Wall · J. D. Schuijf $\cdot$ J. J. Bax \\ J. W. Jukema $\cdot$ M. J. Schalij
}

Received: 23 November 2009/Accepted: 30 November 2009/Published online: 12 December 2009

(C) The Author(s) 2009. This article is published with open access at Springerlink.com

Amongst the advanced cardiac imaging modalities, computed tomography (CT) angiography has emerged as a reliable non-invasive method for the assessment of coronary artery disease (CAD), coronary anatomy and cardiac function [1-17]. Multiple studies involving over several thousands of patients have established that CT angiography is highly accurate for delineation of the presence and severity of coronary atherosclerosis [18-23]. CT angiography may also reveal the total plaque burden, i.e. both calcified and non-calcified components, for individual patients with coronary atherosclerosis [24-35].

Coronary calcification is a marker of atherosclerosis that can be quantified with the use of cardiac CT and it is proportional to the extent and severity of atherosclerotic disease. Several large clinical trials found true incremental predictive value of coronary artery calcium over the Framingham risk score (FRS) when used in asymptomatic patients [36-40]. This relevant prognostic information may be used to initiate or intensify appropriate treatment strategies

Editorial comment on the article of Ahmadi et al. Int $\mathbf{J}$ Cardiovasc Imaging 25:725-738.

E. E. van der Wall $(\bowtie) \cdot$ J. D. Schuijf .

J. J. Bax · J. W. Jukema · M. J. Schalij

Department of Cardiology, Leiden University Medical

Center, P.O. Box 9600, Leiden, The Netherlands

e-mail: e.e.van_der_wall@lumc.nl to slow the progression of atherosclerotic vascular disease. Current data suggests intermediate risk patients may benefit most from further risk stratification with cardiac CT, as coronary artery calcium testing is effective at identifying increased risk. Consequently, there is nowadays sufficient evidence that coronary artery calcium may be considered as useful predictor of coronary artery disease in certain at risk populations such as patients with diabetes, hypertension and in elderly patients [41-43].

Vascular dysfunction is generally considered a key initial event in the atherosclerotic process which is a systemic disorder local manifestation. Functional changes in arteries precede the development of structural changes and also reverse more quickly in response to therapies [44]. Fingertip digital thermal monitoring (DTM) of vascular reactivity is a new noninvasive, operator-independent approach based on changes in fingertip temperature during and after arm cuff occlusion. DTM of vascular function during cuffocclusive reactive hyperemia relies on the premise that changes in fingertip temperature during and after an ischemic stimulus reflect changes in blood flow. Vascular dysfunction measured by DTM has been shown to strongly correlate with FRS and coronary artery calcium independent of age, sex, and traditional cardiac risk factors and was superior to FRS for the prediction of significant coronary artery calcium [45].

In a previous issue of the International Journal of Cardiovascular Imaging Ahmadi et al. [46] evaluated the correlation between DTM and CAD 
measured by CT angiography in 129 symptomatic patients. The authors investigated the correlation between $\mathrm{CT}$ angiography and neurovascular reactivity measured by DTM. All DTM indices of vascular and neurovascular reactivity significantly decreased from normal to non-obstructive to obstructive CAD. Coronary artery calcium increased in each FRS category as vascular dysfunction increased. The most extensive CAD was observed in the group with maximum calcium score and vascular dysfunction, independent of age, gender and traditional cardiovascular risk factors. The authors concluded that vascular dysfunction measured by DTM provided incremental value over FRS for the detection of obstructive and non-obstructive $\mathrm{CAD}$ at $\mathrm{CT}$ angiography.

Previous studies from the same group had already shown strong correlations between low fingertip temperature rebound measured by DTM during a 5minute arm-cuff induced reactive hyperemia and both the FRS, and coronary artery calcification in asymptomatic populations [47]. In another study, Amahdi et al. [48] did already demonstrate that vascular dysfunction measured by DTM was associated with the extent of myocardial perfusion defect independent of age, gender, and cardiac risk factors.

Although large prospective trials are needed to establish the true clinical value of fingertip DTM, the clinical implications are very promising. Patients at risk for $\mathrm{CAD}$, such as patients with hypertension, metabolic syndrome and diabetes mellitus can be easily and noninvasively investigated with the patient-friendly fingertip DTM [49]. In these patients it is of paramount importance to measure and know the status of their vascular function. Fingertip DTM will also allow the evaluation of the effects of pharmacological drugs that influence vascular function. The current study by Ahmadi et al. [46] extends therefore previous findings that fingertip DTM is potentially valuable in the evaluation of at risk individuals in addition to risk factor measurement.

Open Access This article is distributed under the terms of the Creative Commons Attribution Noncommercial License which permits any noncommercial use, distribution, and reproduction in any medium, provided the original author(s) and source are credited.

\section{References}

1. Schuijf JD, Bax JJ, van der Wall EE (2007) Anatomical and functional imaging techniques: basically similar or fundamentally different? Neth Heart J 15:43-44

2. Juwana YB, Wirianta J, Suryapranata H, de Boer MJ (2007) Left main coronary artery stenosis undetected by 64-slice computed tomography: a word of caution. Neth Heart J 15:255-256

3. Wijpkema JS, Dorgelo J, Willems TP et al (2007) Discordance between anatomical and functional coronary stenosis severity. Neth Heart J 15:5-11

4. Bax JJ, Lamb H, Dibbets P, Pelikan H et al (2000) Comparison of gated single-photon emission computed tomography with magnetic resonance imaging for evaluation of left ventricular function in ischemic cardiomyopathy. Am J Cardiol 86:1299-1305

5. van der Wall EE, Heidendal GA, den Hollander W, Westera G, Roos JP (1980) I-123 labeled hexadecenoic acid in comparison with thallium-201 for myocardial imaging in coronary heart disease. A preliminary study. Eur J Nucl Med 5:401-405

6. Bavelaar-Croon CD, Pauwels EK, van der Wall EE (2001) Gated single-photon emission computed tomographic myocardial imaging: a new tool in clinical cardiology. Am Heart J 141:383-390

7. Molhoek SG, Bax JJ, Bleeker GB et al (2004) Comparison of response to cardiac resynchronization therapy in patients with sinus rhythm versus chronic atrial fibrillation. Am J Cardiol 94:1506-1509

8. Thygesen K, Alpert JS, White HD (2007) Universal definition of myocardial infarction; Joint ESC/ACCF/AHA/ WHF Task Force for the Redefinition of Myocardial Infarction. Eur Heart J 28:2525-2538

9. van Lennep JE, Westerveld HT, van Lennep HW, Zwinderman AH, Erkelens DW, van der Wall EE (2000) Apolipoprotein concentrations during treatment and recurrent coronary artery disease events. Arterioscler Thromb Vasc Biol 20:2408-2413

10. Bavelaar-Croon CD, Kayser HW, van der Wall EE et al (2000) Left ventricular function: correlation of quantitative gated SPECT and MR imaging over a wide range of values. Radiology 217:572-575

11. van der Wall EE, van Dijkman PR, de Roos A et al (1990) Diagnostic significance of gadolinium-DTPA (diethylenetriamine penta-acetic acid) enhanced magnetic resonance imaging in thrombolytic treatment for acute myocardial infarction: its potential in assessing reperfusion. Br Heart $\mathbf{J}$ 63:12-17

12. van Dijkman PR, van der Wall EE, de Roos A et al (1991) Acute, subacute, and chronic myocardial infarction: quantitative analysis of gadolinium-enhanced MR images. Radiology 180:147-151

13. van de Wal RM, van Werkum JW, le Cocq d'Armandville MC et al (2007) Giant aneurysm of an aortocoronary venous bypass graft compressing the right ventricle. Neth Heart J 15:252-254 
14. de Leeuw JG, Wardeh A, Sramek A, van der Wall EE (2007) Pseudo-aortic dissection after primary PCI. Neth Heart J 15:265-266

15. Braun S, van der Wall EE, Emanuelsson S, Kobrin I (1996) Effects of a new calcium antagonist, mibefradil (Ro 40-5967), on silent ischemia in patients with stable chronic angina pectoris: a multicenter placebo-controlled study. The mibefradil international study group. J Am Coll Cardiol 27:317-322

16. ten Kate GJ, Wuestink AC, de Feyter PJ (2008) Coronary artery anomalies detected by MSCT-angiography in the adult. Neth Heart J 16:369-375

17. Schuijf JD, Jukema JW, van der Wall EE, Bax JJ (2007) Multi-slice computed tomography in the evaluation of patients with acute chest pain. Acute Card Care 9:214-221

18. Groen JM, Greuter MJ, Vliegenthart R et al (2008) Calcium scoring using 64-slice MDCT, dual source CT and EBT: a comparative phantom study. Int $\mathrm{J}$ Cardiovasc Imaging 24:547-556

19. van Werkhoven JM, Schuijf JD, Jukema JW et al (2008) Anatomic correlates of a normal perfusion scan using 64slice computed tomographic coronary angiography. Am J Cardiol 101:40-45

20. Bakx AL, van der Wall EE, Braun S, Emanuelsson H, Bruschke AV, Kobrin I (1995) Effects of the new calcium antagonist mibefradil (Ro 40-5967) on exercise duration in patients with chronic stable angina pectoris: a multicenter, placebo-controlled study. Ro 40-5967 International Study Group. Am Heart J 130:748-757

21. Schuijf JD, Pundziute G, Jukema JW et al (2006) Diagnostic accuracy of 64-slice multislice computed tomography in the noninvasive evaluation of significant coronary artery disease. Am J Cardiol 98:145-148

22. Jongbloed MR, Lamb HJ, Bax JJ et al (2005) Noninvasive visualization of the cardiac venous system using multislice computed tomography. J Am Coll Cardiol 45:749-753

23. Schuijf JD, Wijns W, Jukema JW et al (2006) Relationship between noninvasive coronary angiography with multislice computed tomography and myocardial perfusion imaging. J Am Coll Cardiol 48:2508-2514

24. Pundziute G, Schuijf JD, Jukema JW et al (2007) Prognostic value of multislice computed tomography coronary angiography in patients with known or suspected coronary artery disease. J Am Coll Cardiol 49:62-70

25. Henneman MM, Schuijf JD, Pundziute G et al (2008) Noninvasive evaluation with multislice computed tomography in suspected acute coronary syndrome: plaque morphology on multislice computed tomography versus coronary calcium score. J Am Coll Cardiol 52:216-222

26. de Nooijer R, Verkleij CJ, von der Thüsen JH et al (2006) Lesional overexpression of matrix metalloproteinase-9 promotes intraplaque hemorrhage in advanced lesions but not at earlier stages of atherogenesis. Arterioscler Thromb Vasc Biol 26:340-346

27. Hoogendoorn LI, Pattynama PM, Buis B, van der Geest RJ, van der Wall EE, de Roos A (1995) Noninvasive evaluation of aortocoronary bypass grafts with magnetic resonance flow mapping. Am J Cardiol 75:845-848

28. van der Laarse A, Kerkhof PL, Vermeer F et al (1988) Relation between infarct size and left ventricular performance assessed in patients with first acute myocardial infarction randomized to intracoronary thrombolytic therapy or to conventional treatment. Am J Cardiol 61:1-7

29. van der Wall EE, den Hollander W, Heidendal GA, Westera G, Majid PA, Roos JP (1981) Dynamic myocardial scintigraphy with $123 \mathrm{I}$-labeled free fatty acids in patients with myocardial infarction. Eur J Nucl Med 6:383-389

30. Vliegen HW, Doornbos J, de Roos A, Jukema JW, Bekedam MA, van der Wall EE (1997) Value of fast gradient echo magnetic resonance angiography as an adjunct to coronary arteriography in detecting and confirming the course of clinically significant coronary artery anomalies. Am J Cardiol 79:773-776

31. van der Hoeven BL, Pires NM, Warda HM et al (2005) Drug-eluting stents: results, promises and problems. Int $\mathbf{J}$ Cardiol 99:9-17

32. Ertaş G, van Beusekom HM, van der Giessen WJ (2009) Late stent thrombosis, endothelialisation and drug-eluting stents. Neth Heart J 17:177-180

33. Pluim BM, Lamb HJ, Kayser HW et al (1998) Functional and metabolic evaluation of the athlete's heart by magnetic resonance imaging and dobutamine stress magnetic resonance spectroscopy. Circulation 97:666-672

34. Scholte AJ, Schuijf JD, Kharagjitsingh AV et al (2008) Different manifestations of coronary artery disease by stress SPECT myocardial perfusion imaging, coronary calcium scoring, and multislice CT coronary angiography in asymptomatic patients with type 2 diabetes mellitus. J Nucl Cardiol 15:503-509

35. Scholte AJ, Schuijf JD, Kharagjitsingh AV et al (2008) Prevalence of coronary artery disease and plaque morphology assessed by multi-slice computed tomography coronary angiography and calcium scoring in asymptomatic patients with type 2 diabetes. Heart 94:290-295

36. Akram K, Voros S (2008) Absolute coronary artery calcium scores are superior to MESA percentile rank in predicting obstructive coronary artery disease. Int $\mathrm{J}$ Cardiovasc Imaging 24:743-749

37. Schenker MP, Dorbala S, Hong EC et al (2008) Interrelation of coronary calcification, myocardial ischemia, and outcomes in patients with intermediate likelihood of coronary artery disease: a combined positron emission tomography/computed tomography study. Circulation 117:1693-1700

38. Rozanski A, Gransar H, Wong ND et al (2007) Clinical outcomes after both coronary calcium scanning and exercise myocardial perfusion scintigraphy. J Am Coll Cardiol 49:1352-1361

39. Scholte AJ, Bax JJ, Wackers FJ (2006) Screening of asymptomatic patients with type 2 diabetes mellitus for silent coronary artery disease: combined use of stress myocardial perfusion imaging and coronary calcium scoring. J Nucl Cardiol 13:11-18

40. Raggi P, Gongora MC, Gopal A, Callister TQ, Budoff M, Shaw LJ (2008) Coronary artery calcium to predict allcause mortality in elderly men and women. J Am Coll Cardiol 52:17-23

41. Brown ER, Kronmal RA, Bluemke DA et al (2008) Coronary calcium coverage score: determination, correlates, and predictive accuracy in the multi-ethnic study of atherosclerosis. Radiology 247:669-675 
42. Detrano R, Guerci AD, Carr JJ et al (2008) Coronary calcium as a predictor of coronary events in four racial or ethnic groups. N Engl J Med 358:1336-1345

43. Sirineni GK, Raggi P, Shaw LJ, Stillman AE (2008) Calculation of coronary age using calcium scores in multiple ethnicities. Int J Cardiovasc Imaging 24:107-111

44. Marques KM, Westerhof N (2008) Characteristics of the flow velocity-pressure gradient relation in the assessment of stenoses: an in vitro study. Neth Heart J 16:156-162

45. Ahmadi N, Hajsadeghi F, Gul K et al (2008) Relations between digital thermal monitoring of vascular function, the Framingham risk score, and coronary artery calcium score. J Cardiovasc Comput Tomogr 2:382-388

46. Ahmadi N, Nabavi V, Nuguri V et al (2009) Low fingertip temperature rebound measured by digital thermal monitoring strongly correlates with the presence and extent of coronary artery disease diagnosed by 64-slice multidetector computed tomography. Int J Cardiovasc Imaging 25:725-738

47. Gul KM, Ahmadi N, Wang Z et al (2009) Digital thermal monitoring of vascular function: a novel tool to improve cardiovascular risk assessment. Vasc Med 14:143-148

48. Ahmadi N, Usman N, Shim J et al (2009) Vascular dysfunction measured by fingertip thermal monitoring is associated with the extent of myocardial perfusion defect. $\mathbf{J}$ Nucl Cardiol 16:431-439

49. Ahmadi N, Hajsadeghi F, Gul K et al (2009) Vascular function measured by fingertip thermal reactivity is impaired in patients with metabolic syndrome and diabetes mellitus. J Clin Hypertens (Greenwich) 11:678-684 